\section{CASE OF (ESOPHAQOTOMY.}

BY EDWARD LAWRIE,

PROFESSOR OF SURGERY IN TIIE LAIIORE MEDICAL SCIIOOL.

A SrKu female, aged thirty-five, was admitted into Mayo Hospital on Dec. 14ch, 1833, with a large gall.nut impacted in the gullet. She had been suffering previously from an affection of the eye, and was told by a $f_{i}$ iend that if she held a gall-nut in her mouth for two hours she would be cured While giving this plan of treatment a $t_{1} i_{i}$ l the nut slipped down her throat and lodged in the cervical portion of the csophague. During the twenty-four hours following her admission every attempt to dislodge it failed. On the 15 th the patient was very low and distressed, and it was decided after consultation with my colleagues to perform oesnphagotomy. The operation was carried out in the usual way by dissection through the loose cellular tissue between the carotid vessels and the trachea till the foreign body was felt through the walls of the cesophagus, which was opened by a longitudinal incision and the nut removed. The woman was fed through a tube for five days, swallowing was perfectly restored in twelve days, and she was discharged cured in three weeks.

Lahore.

\section{9 attituror}

\section{HOSPITAL PRACTICR, BRITISH AND FOREIGN.}

Nullaautem estalia procerto noscendivia, nisi quamplu rimas et morborum et dissectionum historias, tum aliorum tum proprias collectas habere, e Inter se comparare.-Morgagri De Sed. et Oaus. Morb., lib. iv. Proomium.

\section{ST. BARTHOLOMEW'S HOSPITAL.}

A CASE OF DIFFUSED POPLITEAL ANEURISM, TREATED FIRST BY COMPRESSION, AND SUBSEQUENTLY BY LIGATURE OF THE SUPERFICIAL FEMORAL ARTERY IN SCARPA'S TRIANGLE.

(Under the care of Mr. MorRANT B.IKER.)

For the notes of the following case we are indebted to Mr. H. B. Tait, house-surgeon.

The patient, aged thirty-five, a well-nourished man of medium height, was admitted on Sept. 10th, 1883. He was originally a groom and coachman, his work consisting chiefly of driving, but for the last three years he had followed the trade of a hawker. There was an iodefinite history of ayphilis fifteen years ago, and a history of smallpox seven years ago, but of no other illness. The patient had at the time of admission an indurated chancre on the penis, with shotty glands in the groin; he had neither rash nor sore-throat. Ou Sept. 2od he first noticed a swelling about the size of a hen's egg iu the right popliteal space, but did not come to the hospital until the $7 \mathrm{tb}$, and even then refused treatment until the $10 \mathrm{th}$, when he was admitted to Harley ward. He said that on Sept. 7 th and 8 th he walked a great deal, and afterwards suffered considerable pain in the limb. On Sept. 9th the pain increased so that he remained in bed.

On admission, the right popliteal region was found to be occupied by a large pulsating tumour, which had a distinct bruit. The pulsation was easily controlled by pressure on the femoral artery in the groin; the leg and thigh were also considerably swollen. The measurements were as follows :Right leg: middle of thigh, nineteen inches and a half ; round knee, sixteen iaches and a half ; round calf, sixteen inches. Left leg : middle of thigh, eighteen inches and a half; round knee, thirteen inches and a half ; round calf, thirteen inches.

On Sept. 1 lith the patient was fairly comfortab'e. Onesixth of a grain of morphia was administered hypodermically the night before. The pulsation seemed slightly less. On Sept. 12 th the pulsation was more marked. The measurements round the thigh and knee had increased half an inch respectively. The patient had suffered a good deal of pain during the early part of the night, but was comfortable after a hypodermic injection of one-sixth of a grain of morphia.
It being decided to try compression for twenty.four hours, a small pad was placed on the artery in the groin, and a shot-bag weighing $14 \mathrm{lb}$, was used as a weight. Pressure was commenced about 3 I'. M. At 5 r. Mr. it was noticed that the swelling of the limb had increased, and that the integument over the tumour and upper part of the leg was dis coloured. At 6 P.M. digital pressure was substituted for that of the parl, the shot-bag being used as before. At 7 P.M. the measurement round the knee had increased an inch and a quarter, that round the calf having also increased seven eighths of an inch. At 7.45 I. Mr. all pressure was discon tinued. It being, however, found that the limb became still more swollen, and that the discolouration was increasing digital pressure without the weight was again applied, until Mr. Buker's arrival, when all pressure was again discontinued, At 10.30 the patient was taken to the theatre, and Mr. Baker tied the superficial femoral artery in Scarpa's triangle, the leg being first wrapped in cotton-wool, and bandaged with flannel. The artery was tied in two places with kangaroo tendon, and divided between the ligatures. Catgut surures and sanitas oil dressing were used, a strip of gutta-percha tissue being employed for drainage.

On Sept. 13th the leg and ihigh were much less tense. There was no pulsation in the aneurism; the foot was quite warm and sensation good; there was hardly any discharge from the wound. The patient complained of very little pain. Evening temperature normal, morning $992^{\circ}$; pulse 76 , regular. He took iced milk well. One-third of a grain of morphia was injected hypodermically at night. On the 14th the wound was lo sking well; two stitches were removed. The patient was comfortable, and had a good night without morphia. On the l5th the bowels were open three times after castor oil. The patient was free from pain, his tem. perature being normal. On the 17 th the wound was looking very well; all sutures and drainage were removed.

On Oct. lst there was some hardness, and very slight discolouration in the popliteal region. On the 8 th the patient got up for the first time. On the 13 th there was still some hardness, and slight discolouration in the popliteal region. The measurements were as follows:-Right leg: round thigh, nineteen inches; round knee, fourteen inches and a half; round calf, twelve inches and a half. Left leg: round thigh, eighteen ioches and three-quarters; round knee, fourteen inches ; round calf, thirteen inches.

The patient left the hospital on Oct. 15 th, and when seen argain some weeks afterwards was quite well.

Remarlis. - It was not considered very probable in this case that pressure would cure the patient's aneurism. But he was much frightened at the idea of any operation, and it seemed likely at the time that he would leave the hospital if its consideration were pressed upon him. Pressure was therefore tentatively employed, but the leaking of blood from the aneurism, which had probably begun before the patient's admission in to the hospital, was not restrained, and it became imperatively necessary to tie the artery without delay. Mr. Baker remarked, "That each case must be treated on its own merits; extravasation of blood beyond the immediate limits of the aneurism might seem at first sight to contra-indicate altogether the employment of pressure; but in the filteenth volume of the St. Bartholomew's Hospital Reports a case was recorded in which extravasation bad gradually occurred to such an extent as to obscure the diagnosis by almost stopping the pulsation, and in which notwithstanding, the aneurism was easily and quickly cured by digital pressure with the help of Esmarch's bandage." In the present case Esmarch's bandage was clearly inappli cable, and digital pressure was applied for a few hours only, and with much caution. This case is the second within the past year in which Mr. Baker has tied the femoral artery by kangaroo tendon ligatures, dividing the artery between them.

\section{LIVERPOOL NORTHERN HOSPITAL.}

CASE OF LARGE SALIVARY CALCULUS; EXCISION OF SUBMAXILLARY GLAND.

(Under the care of Mr. Chauncy Puzey.)

THE following case seems to be notewortby, not merely on account of the unusual size of the calculus, but because of other circumstances which will appear in the record.

The patient, a woman aged about thirty.five, was under Mr. Puzey's care in the Northern Hospital two years before on account of a mass of tuberculous glands, the size of a man's fist in the left axilla. Excision was performed the 